\title{
THE FECUNDITY OF ENGLISH CHANNEL PLAICE
}

\author{
By T. B. BAgenaL \\ The Marine Station, Millport
}

(Text-figs. I-2)

This paper is the fourth in a series dealing with the fecundity of flatfish (Bagenal $1957 a, b, 1958)$, and is concerned with the egg numbers in ripening female plaice Pleuronectes platessa L. caught in the English Channel.

On 27 November 1957, eighty-five plaice with maturing ovaries were caught in Rye Bay, Sussex; on I December, eight similar fish were caught in Lyme Bay, and during December sixty-four locally caught female plaice were brought in to the Plymouth Laboratory. The dates of the collections were chosen because in January 1957 I had found that a small proportion of the Plymouth plaice were spent. All the fish caught in November and December were at a suitable stage for fecundity estimation: that is, the eggs were well developed though none had begun to turn translucent.

The treatment of the fish was similar to that already described (Bagenal, I957a) for long rough dabs, except that the Rye Bay and Lyme Bay plaice were weighed on a spring balance to the nearest quarter ounce and these weights were subsequently transformed to grammes; the Plymouth fish were weighed to the nearest $5 \mathrm{~g}$. The paper on long rough dabs should be consulted for details of the laboratory methods of preservation, the estimation of the fecundity and the statistical analysis of the data.

I would like to thank Captain C. A. Hoodless and the crew of R.V. 'Sarsia' for their help at sea and Mr A. D. Mattacola and the Plymouth Laboratory staff for their help on land and also Miss Sheila Morris who counted the eggs.

\section{RESULTS}

The data are summarized in Tables $I$ and 2 along with the fecundity data for the Clyde (from Bagenal, 1958) and for the Southern Bight of the North Sea (from Simpson, I95I). The relations of fish length and fecundity are shown in Figs. I and 2. The relations of age and fecundity are given in Table 3.

\section{Plymouth}

The fecundity of the Plymouth female plaice is the same as that of the Clyde fish; the difference between the two values for the expected fecundity $(\hat{F})$ of a $37 \mathrm{~cm}$ plaice could easily be due to random subsampling errors. 
Simpson (1957) has found the fecundity of plaice from the Irish Sea to be similar to Clyde and Plymouth fish. The nearest locality from which he determined the fecundity was Cardigan Bay. It would be interesting to know the fecundity of the plaice that spawn off St Ives.

Plaice seem to be rare off Plymouth until mid-December at which time they begin to appear in increasing numbers prior to spawning in early January. We do not know where they come from.

TABLE 1. SUMMARY OF PLAICE FECUNDITY DATA

Number of fish

Mean length $(\mathrm{cm})$

Mean weight (g.)

Mean age

Mean fecundity

$\hat{\mathrm{W}}$ for $37 \mathrm{~cm}$

F for $37 \mathrm{~cm}$
Clyde

$6 \mathrm{r}$

$38 \cdot 33$
$585 \cdot 8$

$5 \cdot 2$
158,845

526.4

137,266

Plymouth

64
$42 \cdot 47$
$758 \cdot 8$
$6 \cdot 3$
212,769
$516 \cdot 4$
137,470

Lyme Bay

8

$37 \cdot 57$
$688 \cdot \mathrm{I}$

$5 \cdot 0$

255,888

$66 \mathrm{I} \cdot 4$

244,3 I I

Rye Bay North Sea

TABLE 2. THE MEAN FECUNDITY (IN THOUSANDS) OF EACH 3 CM LENGTH GROUP OF ENGLISH CHANNEL FEMALE PLAICE

\begin{tabular}{|c|c|c|c|c|c|c|}
\hline \multirow{2}{*}{$\begin{array}{l}\text { Length } \\
\text { group }\end{array}$} & \multicolumn{2}{|c|}{ Plymouth } & \multicolumn{2}{|c|}{ Lyme Bay } & \multicolumn{2}{|c|}{ Rye Bay } \\
\hline & Number & Fecundity & Number & Fecundity & Number & Fecundity \\
\hline 30 & - & - & - & - & 6 & $70 \cdot 21$ \\
\hline 33 & 5 & 125.06 & 4 & $172 \cdot 80$ & 23 & $89 \cdot 62$ \\
\hline 36 & 8 & II 3.88 & 2 & I3 I 20 & 16 & I $17 \cdot 82$ \\
\hline 39 & Io & 129.62 & 一 & - & I4 & 125.83 \\
\hline 42 & I3 & $207 \cdot 71$ & I & 324.95 & 12 & 186.60 \\
\hline 45 & I4 & $247 \cdot 20$ & - & - & 6 & 173.25 \\
\hline 48 & 8 & 266.62 & - & - & 2 & 250.60 \\
\hline $5 I$ & 3 & 313.82 & - & - & 2 & 268.53 \\
\hline 54 & 2 & 419.85 & - & - & I & $230 \cdot 35$ \\
\hline 57 & - & - & I & $768 \cdot 55$ & I & $264 \cdot 15$ \\
\hline 60 & I & 709.55 & 一 & - & 一 & - \\
\hline 63 & - & - & 一 & - & 2 & $442 \cdot 63$ \\
\hline
\end{tabular}

Rye Bay

The fecundity of the eighty-five Rye Bay plaice is intermediate between that of Plymouth and North Sea fish. From marking experiments in Rye Bay (Wimpenny, 1953) we know that the plaice migrate both into the North Sea and to the west. Wimpenny's results are summarized below.

$\begin{array}{llccc}\text { Released } & \text { No. } & \begin{array}{c}\text { Local } \\ \text { returns }\end{array} & \begin{array}{c}\text { Eastward } \\ \text { movement }\end{array} & \begin{array}{c}\text { Westward } \\ \text { movement }\end{array} \\ \text { January } & 300 & 56 & 31 & 4 \\ \text { April } & ? & 87 & 49+ & - \\ \text { July } & \text { No tendency to move to the westward } & \text { Suggested that what little movement there had been } \\ \text { October } & \text { Sas in a westerly direction } & \end{array}$

Three of the four westerly moving plaice were caught off Brixham (West end of Lyme Bay) and one from off South Ireland. Mixtures of west channel and 
North Sea plaice in the ratio of $4: 31$ should produce a mean fecundity for $37 \mathrm{~cm}$ fish of between 90 and I02 thousand eggs.

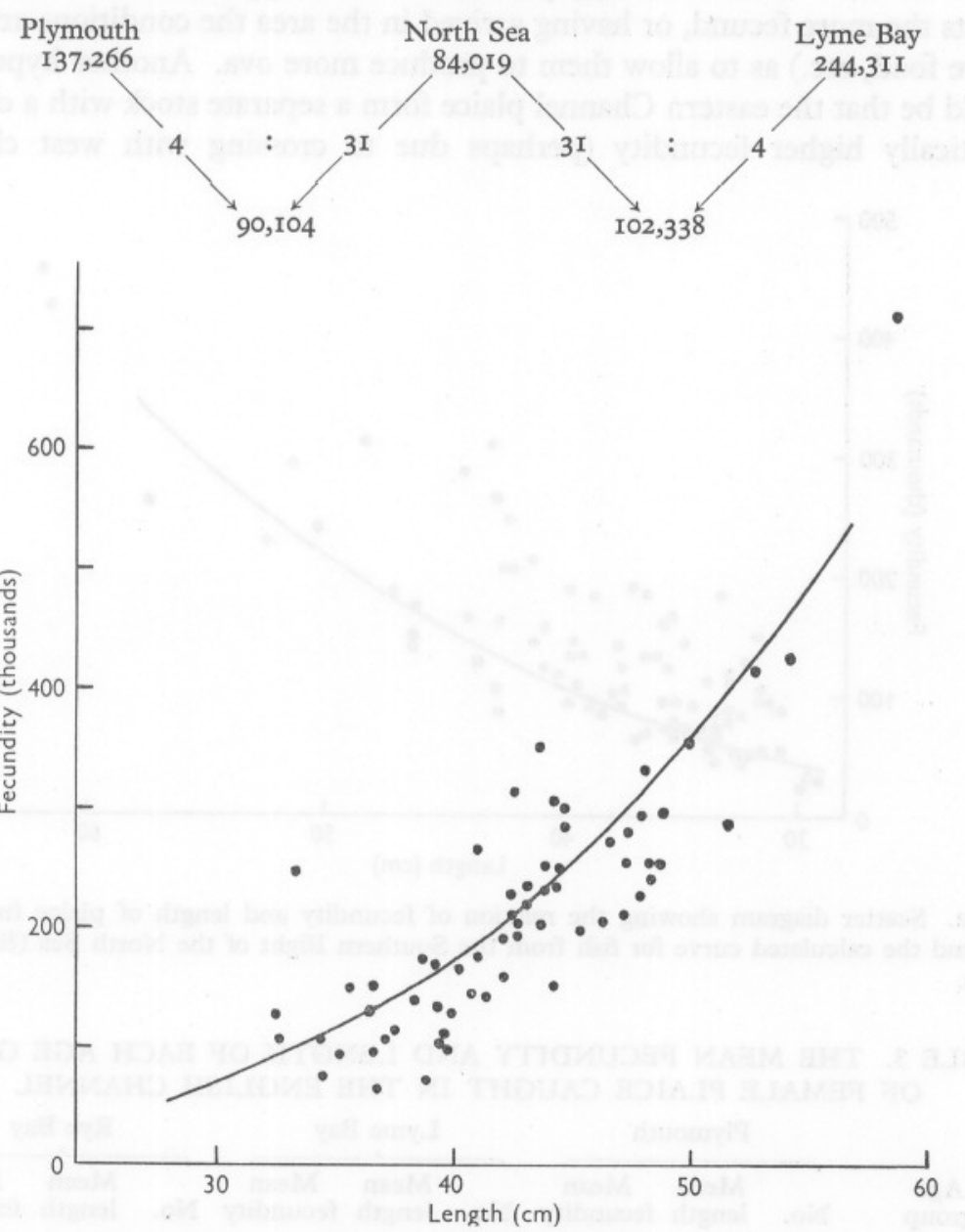

Fig. I. Scatter diagram showing the relation of fecundity and length of plaice from Plymouth and the calculated curve for Clyde fish (Bagenal, 1958).

The actual fecundity of 127 thousand eggs for $37 \mathrm{~cm}$ plaice might be the average of fish mainly derived from the North Sea, but with a mixture of more plaice from the west than marking experiments suggest do exist in the area: over one-third of the population would have to be of western origin. Moreover, the scatter diagram (Fig. 2) shows that the general level of fecundity for the Rye Bay population as a whole is above that of the North Sea.

Simpson (1959) discusses the spawning of North Sea plaice and believes that 'the spawning area in the eastern English Channel is not an independent 
spawning area, but is, in effect, a spill-over from the main Southern Bight area'. If this is true either the spill-over is not of typical North Sea fish but selects the more fecund, or having arrived in the area the conditions are such (more food, etc.) as to allow them to produce more ova. Another hypothesis would be that the eastern Channel plaice form a separate stock with a characteristically higher fecundity (perhaps due to crossing with west channel

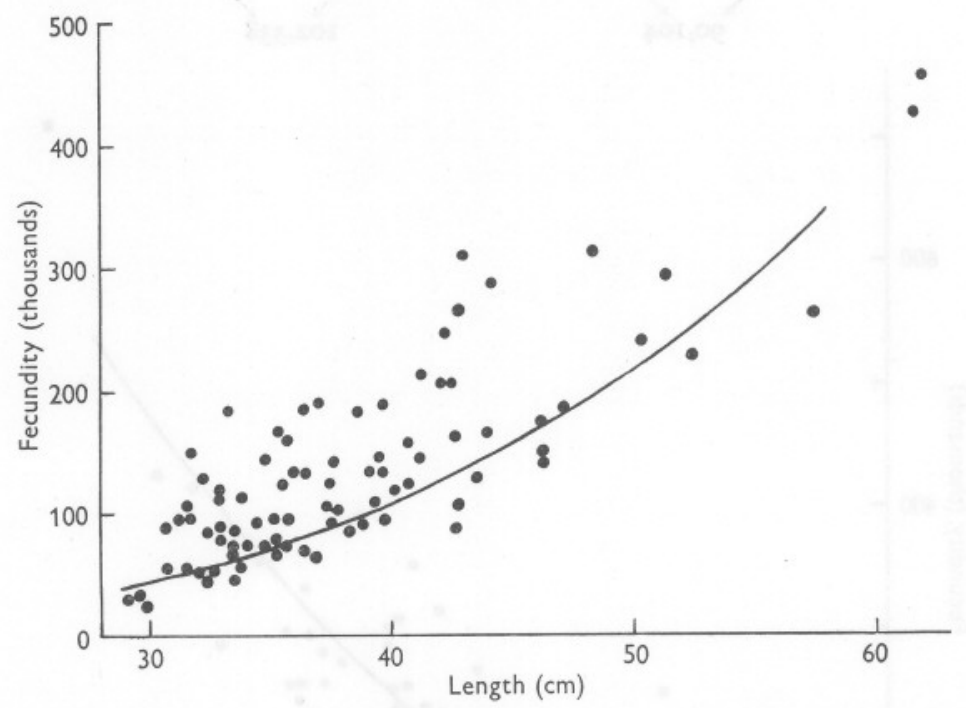

Fig. 2. Scatter diagram showing the relation of fecundity and length of plaice from Rye Bay and the calculated curve for fish from the Southern Bight of the North Sea (Simpson, 195I).

TABLE 3. THE MEAN FECUNDITY AND LENGTH OF EACH AGE GROUP OF FEMALE PLAICE CAUGHT IN THE ENGLISH CHANNEL

\begin{tabular}{|c|c|c|c|c|c|c|c|c|c|}
\hline \multirow[b]{2}{*}{$\begin{array}{l}\text { Age } \\
\text { group }\end{array}$} & \multicolumn{3}{|c|}{ Plymouth } & \multicolumn{3}{|c|}{ Lyme Bay } & \multicolumn{3}{|c|}{ Rye Bay } \\
\hline & No. & $\begin{array}{l}\text { Mean } \\
\text { length }\end{array}$ & $\begin{array}{c}\text { Mean } \\
\text { fecundity }\end{array}$ & No. & $\begin{array}{l}\text { Mean } \\
\text { length }\end{array}$ & $\begin{array}{c}\text { Mean } \\
\text { fecundity }\end{array}$ & No. & $\begin{array}{l}\text { Mean } \\
\text { length }\end{array}$ & $\begin{array}{c}\text { Mean } \\
\text { fecundity }\end{array}$ \\
\hline II & - & - & - & - & - & - & 4 & $3 r \cdot 3$ & $96 \cdot 4$ \\
\hline III & 4 & $36 \cdot 2$ & $162 \cdot I$ & 2 & $32 \cdot 7$ & $242 \cdot 6$ & 10 & & $77 \cdot 6$ \\
\hline IV & 4 & $38 \cdot 6$ & 164.9 & I & $36 \cdot 2$ & 158.8 & 9 & 34.9 & $124: 3$ \\
\hline V & I5 & $40 \cdot 6$ & 172.8 & 3 & $33 \cdot I$ & 103.2 & 16 & $34 \cdot 6$ & 107.8 \\
\hline VI & II & $42 \cdot 3$ & 198.6 & I & $4 \mathrm{I} \cdot 8$ & $325 \cdot 0$ & I3 & $37 \cdot 6$ & 124.0 \\
\hline VII & I2 & $4 \mathrm{I} \cdot 5$ & I 83.6 & - & - & - & 9 & 37.0 & $122 \cdot 9$ \\
\hline VIII & 6 & 46.9 & $298 \cdot 5$ & - & - & - & 4 & $42 \cdot 7$ & $22 \mathrm{I} \cdot \mathrm{I}$ \\
\hline IX & 6 & $46 \cdot 6$ & $239 \cdot 3$ & I & $57 \cdot 9$ & $768 \cdot 6$ & 8 & $43 \cdot 3$ & 139.3 \\
\hline & 2 & 53.4 & 419.9 & - & - & - & 3 & 43.7 & 154.0 \\
\hline XI & - & & - & - & - & - & 2 & $44 \cdot 5$ & $206 \cdot 0$ \\
\hline XII & - & - & - & - & - & - & 2 & $46 \cdot 7$ & $277 \cdot$ I \\
\hline XIII & - & - & - & - & - & - & - & & \\
\hline XIV & - & - & - & - & - & - & I & $52 \cdot 5$ & $230 \cdot 4$ \\
\hline $\mathrm{XV}$ & - & - & - & - & - & - & I & $57 \cdot 5$ & $264 \cdot 2$ \\
\hline XVI & - & - & - & - & - & - & I & $51 \cdot 3$ & $296 \cdot 6$ \\
\hline XVII & - & - & - & - & - & - & I & & 427.9 \\
\hline
\end{tabular}


fish). This would involve the return of those adult fish that migrate into the North Sea as well as the return of the young that have drifted there as eggs and larvae The return of young to the exact breeding place of their parents is well known in salmonids and birds.

The growth rate of eighty-five Rye Bay plaice as shown in Table 3 is comparable to that given by Wimpenny (1947) after allowance is made for the time of year of the collections. The rate of growth is faster than that of North Sea plaice, and this is similar to the situation at Flamborough.

It is perhaps significant that the smaller areas such as Flamborough and Rye Bay that are out-lyers of the main North Sea plaice grounds carry stocks with higher fecundities, and faster growth rates.

\section{Lyme Bay}

The eight Lyme Bay plaice have a high mean fecundity but this is to some extent increased by one fish of $58 \mathrm{~cm}$ in length which was exceptionally fecund.

Four hours fishing off Brighton, and some $\mathrm{I} 2 \mathrm{~h}$ trawling in Poole Bay did not yield any plaice and the eight females from Lyme Bay were caught in over $4 \mathrm{~h}$ fishing.

In the middle region of the Channel therefore plaice are very scarce in late November, and even at Plymouth they do not appear to become plentiful until mid-December. It is not possible at this stage to confirm an inverse relation between fecundity and population density, because of the complications imposed by migration. Nor is a relation between fecundity and condition immediately apparent. This is shown by the North Sea plaice which were in better condition than those in Rye Bay (a $37 \mathrm{~cm}$ fish has a heavier expected weight) but had a lower fecundity.

\section{SUMMARY}

The plaice off Plymouth are shown to have a level of fecundity comparable to the Irish Sea and Clyde. The plaice in Rye Bay have a fecundity intermediate between that of the Clyde-Irish Sea-Plymouth fish, and the North Sea plaice, but this is apparently not produced by a mixing of the two populations, either the environment favours a high fecundity, or the Eastern Channel plaice form a separate stock.

\section{REFERENCES}

BAgenal, T. B., I957a. The breeding and fecundity of the long rough dab Hippoglossoides platessoides (Fabr.) and the associated cycle in condition. F. mar. biol. Ass. U.K., Vol. 36, pp. 339-73.

_ 1957b. Annual variations in fish fecundity. F. mar. biol. Ass. U.K., Vol. 36, pp. $377-82$.

— I958. The fecundity of Clyde plaice. F. mar. biol. Ass. U.K., Vol. 37, pp. 309I3. 
Simpson, A. C., I95I. The fecundity of the plaice. Fish. Invest., Lond., Ser. 2, Vol. I7, No. $5,27 \mathrm{pp}$.

- 1957. The spawning of the plaice (Pleuronectes platessa) in the Irish Sea. Paper No. 54 read at the annual meeting of I.C.E.S., Bergen, I957.

- 1959. The spawning of plaice in the North Sea. Fish. Invest., Lond., Ser. 2, Vol. 22, No. 7, III pp.

Wimpenny, R. S., 1947. The Rye Bay plaice stock in the war of 1939-45. Ann. biol., Copenhague, Vol. 2, 68-74.

1953. The Plaice. $145 \mathrm{pp}$. London. 